\title{
Geochemical features of the microbial carbonate from the Jiudingshan Formation, the Huaibei Group: implications for palaeoenvironment
}

\author{
CHENQING LI, LIN DONG AND BING SHEN
}

Peking University

Presenting Author: chenqingli@pku.edu.cn

The earth was thought to have a stable climate-plate tectonic system, a low oxygen level, and invariable Carbon, Chromium isotopic records from late Mesoproterozoic to early Neoproterozoic (1800 to $800 \mathrm{Ma}$, the Boring Billion). In order to constrain the sea-floor redox during this time, we focus on the microbial carbonates of the Jiudingshan Formation from the Huaibei Group in Xuzhou, Jiangsu Province and conduct petrological and geochemical research.

The Jiudingshan Formation mainly consists of light gray microbial and dolomitic limestones, with minor chert nodules which contain well preserved filamentous cyanobacteria and spherical microfossils. We measured the major and trace elements, carbon and oxygen isotopes of dolomitic microbial limestone, micritic limestone and intraclast limestone with micro-drill sampling, guided by detailed petrological observation. Carbonate associated ferrous iron $\left(\mathrm{Fe}_{\text {carb }}\right)$ values (ranges from 17.3 to $81.4 \mathrm{ppm}, 37.3 \mathrm{ppm}$ in average) are consistently low in the micritic limestone samples which have low $\mathrm{Mg} / \mathrm{Ca}$ ratios $(<0.01 \mathrm{~mol} / \mathrm{mol})$. We use the sedimentation rates of the carbonates from the late Ediacaran Dengying Formation, from the Devonian Wuzhishan, Rongxian Formation and from the modern stromatolites as analogs, and the result of the simulation show that the seafloor $\mathrm{O}_{2}$ fugacity ranges from $123 \mu \mathrm{mol} / \mathrm{L}$ to $234 \mu \mathrm{mol} / \mathrm{L}$ with sediment rate from $10 \mathrm{~m} / \mathrm{Myr}$ to $30 \mathrm{~m} / \mathrm{Myr}$. The estimation of the $\mathrm{O}_{2}$ fugacity suggests that the contemptuous seafloor was oxic. The formation of this local oxygen-enriched habitat may be attributed to the benthic microbial mats that produced abundant oxygen through photosynthesis and thus accumulated oxygen at the watersediment interface. This local oxic oasis may provide appropriate environment for the up-coming evolution of benthic animals. 